\title{
PHBS (Clean and Healthy Living Habits) As Covid 19 Prevention Education for Early Childhood
}

\author{
Abdullah $^{1 凶}$, Handono Fatkhur Rahman ${ }^{2}$, Wiwin Warliah ${ }^{3}$, Nur Qomariah ${ }^{4}$, Sutriyani $^{4}$ \\ Pendidikan Agama Islam, Universitas Nurul Jadid, Paiton, Probolinggo, Indonesia(1); Ilmu \\ Keperawatan, Universitas Nurul Jadid, Paiton, Probolinggo, Indonesia(2); Komunikasi \\ Penyiaran Islam, Universitas Nurul Jadid, Paiton, Probolinggo, Indonesia(3); Pendidikan \\ Islam Anak Usia Dini, Universitas Nurul Jadid, Paiton, Probolinggo, Indonesia ${ }^{(4)}$ \\ DOI: $\underline{10.31004 / o b s e s i . v 6 i 4.2075}$
}

\begin{abstract}
This research was motivated by the PHBS movement (Habitat for Clean and Healthy Life); PHBS was carried out at an early childhood education program, namely Raudlatul Athfal, located in the village of Pakunira. This study aims to determine how PHBS in children is early prevention of COVID 19. This study used a descriptive qualitative approach. Data collection techniques using interviews, observation, and documentation. After that, it is processed through data triangulation. PHBS is carried out in preparation and planning analysis, PHBS program implementation, and program evaluation based on the research findings. This research has implications for covid-19 prevention education through PHBS to provide the understanding and habituation to healthy lifestyles for students, teachers, parents, and the school environment.
\end{abstract}

Keywords: phbs education; covid 19; early childhood

\begin{abstract}
Abstrak
Penelitian ini dilatarbelakangi adanya gerakan PHBS (Pembiasaan Hidup Besrih dan Sehat) yang dilakukan pada sebuah pendidikan anak usia dini yaitu Raudlatul Athfal yang berada di desa pakunira. Penelitian ini bertujuan untuk mengetahui bagaimana penerapan PHBS pada anak-anak sebagai upaya pencegahan dini COVID 19. Penelitian ini menggunakan pendekatan kualitatif jenis deskriptif. Teknik pengumpulan data menggunakan wawancara, observasi, dan dokumentasi. Setelah itu diproses melalui triangulasi data. Berdasarkan hasil temuan penelitian PHBS dilakukan dengan cara; Analisi persiapan dan perencanaan, Implementasi program phbs dan Evaluasi program. Penelitian ini memberikan implikasi dengan edukasi pencegahan covid-19 melalui PHBS mampu memberikan pemahaman dan memberikan pembiasaan pola hidup sehat baik untuk anak didik, guru, wali murid dan lingkungan sekolah
\end{abstract}

Kata Kunci : edukasi phbs; covid 19; anak usia dini

Copyright (c) 2022 Abdullah, et al.

$\triangle$ Corresponding author :

Email Address : abdullah@unuja.ac.id (Probolinggo, Indonesia)

Received 15 November 2022, Accepted 28 December 2022, Published 1 March 2022 


\section{INTRODUCTION}

The emergence of the COVID-19 outbreak in almost all countries in the world caused significant changes and impacted all aspects of life (Mustajab \& Fawa'iedah, 2020; Rahman \& Subiyantoro, 2021). Its main fields include economics, health, tourism, and education. Great concern for the emergence of this virus is due to several reasons, including the speed of transmission of the virus that attacks the immune system, which can cause death (Fahrika \& Roy, 2020; Suhairi \& Badrudin, 2021). During the COVID-19 outbreak, fundamental changes occurred in society (Adham \& Mahmudah, 2021). These changes are related to behavior that must comply with health protocols, such as maintaining a clean and healthy lifestyle, maintaining distance, wearing masks, and not shaking hands (Apriliani et al., 2020; Dewi, 2021).

The Indonesian demographic and health survey results in 2017 show that 93\% of Indonesians are accustomed to washing their hands using soap and running water. The habit applied by the community by washing their hands with soap and clean water shows that the Indonesian people already have a good habit of washing their hands using soap and running water. It's just that during this pandemic situation, there is an increase. One of the ways to prevent the COVID-19 virus, as recommended by the government, is to wash your hands with soap and running water until your hands are clean (Rifqi, 2021). Should not touch the face, including the nose, eyes, and mouth, if the hands are dirty. If there is no soap and water, it is recommended to wash your hands using hand sanitizer.

Maintaining health is essential initially, namely in PAUD school-age children; this is important because children are prone to disease. After all, children's immune system is not yet mature in general (Khomaeny et al., 2020; Andin et al,. 2021). Pamungkas et al,. (2021) Said, children usually put their hands in their mouths; whatever object they hold then they try to eat it, so they don't know if it's dirty or not, they don't know, it becomes a danger when children are not taught accustomed to living clean.

Children who have good health will have optimal growth and children's health standards (Iltiqoiyah, 2020), which include a physical and psychological change in general and have developed according to their age (Kamelia, 2019; Ariyanti, 2016). Pujianto (2019) and Afrida et al,. (2020) Said that children during the exploration period had the characteristics of good health, seemed cheerful, enthusiastic about playing, shouted, ran, jumped, and usually did not want to stay still. Healthy children generally have optimal development according to the child's age, develop psychologically according to the child's level of maturity and age, are active, happy and have a regular diet, and can socialize with the surrounding environment (Sukatin at al,. 2020; Agusniatih, \& Manopa, 2019; Dewi, 2016)

Environmental health maintenance in schools is focused on monitoring various environmental factors that facilitate the onset of disease or affect the health status of children (Mustain et al,.2021). Getting used to maintaining cleanliness cannot be separated from the behavior of teachers and children in strengthening personal and environmental hygien. In line with the opinion Hakiki \& Khotimah (2020)) that environmental protection is, for example, game tools are arranged neatly in the playing environment. Another safeguard is to familiarize children with personal hygiene (Hayati, 2019; Nurhasanah, 2019). If clean habits have been instilled from an early age, they will behave according to hygiene norms when they grow up.

Maintaining cleanliness needs to be encouraged, especially at the Raudlatul Athfal institution. The facts on the ground show that the habits of the community and students at Raudlatul Athfal are not aware of the importance of cleanliness, which can be seen in the practices of students who are less interested in washing their hands, using hand sanitizers, and using masks even though at this time the virus and diseases are easily spread from various media and activities carried out by students. This is due to teachers' lack of innovation and motivation in promoting clean and healthy living behavior and awareness about cleanliness. 
In realizing the quality and competitive human resources (Mundiri \& Jannah, 2021), health builders are directed to increase awareness, willingness, and ability to live healthy for everyone, especially students. Healthy culture habituation can be realized through PHBS (Clean and Healthy Living Behavior). PHBS is used as a solution by teacher Raudlatul Athfal in overcoming phenomena that occur in institutions and the surrounding environment.

This research is based on research premia by Julianti et al., (2018) Nurmahmudah et al., (2018), which says that the implementation of PHBS is a collection of behaviors that are practiced based on awareness. As a result of learning. Furthermore, by Mardhiati (2013), Clean and healthy living behavior aims to form preventive behavior against disease. Then also confirmed by Julianti et al,. (2018). All health is carried out based on awareness so that families or family members can help themselves in the health sector and play an active role in health activities in the community is another meaning of PHBS. PHBS learning needs to be appreciated so that children realize from an early age the importance of the definition of healthy (Tabi' in 2020). In addition, the PHBS pattern aims to motivate children to play an essential role in realizing physical health or body health; the development of a sound health system, the development of a good health system are carried out. One of the targets of environmental health development is not schools because schools provide education for children and result from a social-ecological health system (Tabi' in, 2020).

Departing from the existing background, the researchers are interested in integrating the PHBS concept in preventing the covid-19 virus and maintaining students' health. This research focuses on analyzing and understanding how to implement PHBS at an early age to overcome the virus.

\section{METHODOLOGY}

This study uses a descriptive type of qualitative approach. Used a qualitative approach to gain an in-depth understanding of the implementation of clean and healthy living behavior in early childhood at a Raudlatul Athfal school in Pakuniran village to prevent COVID-19. Research that uses a qualitative approach, the primary data source is obtained from words and actions, the rest is additional data such as documents and others lain (Rahmawati et al., 2020). The research results are described and understood in the form of appropriate and systematic language expressions based on the facts in the research.

Conducted this research at an early childhood education institution, namely Raudlatul Athfal, located in the village of Pakuniran, which was conducted on children with an age range of 4-6 years in the school. Conducted this research since the emergence of COVID 19. The research subjects were 32 early childhood children at Raudlatul Athfal, the principal, and three teachers who taught at the school.

The data collection method used documentation by the direction of the research, interviews, and in-depth observations. The data obtained by the researcher from discussions, documentation, and comments were then processed and combined. This activity has the aim of producing data that is accurate and capable of being responsible for its authenticity. Data analysis was carried out from the start of the study to the preparation of the final manuscript of the study. The concept used in this study flows analysis (flow model analysis), namely the idea of analysis which includes the following stages; collect data, display data, draw conclusions, and verify (Wijaya, 2020).

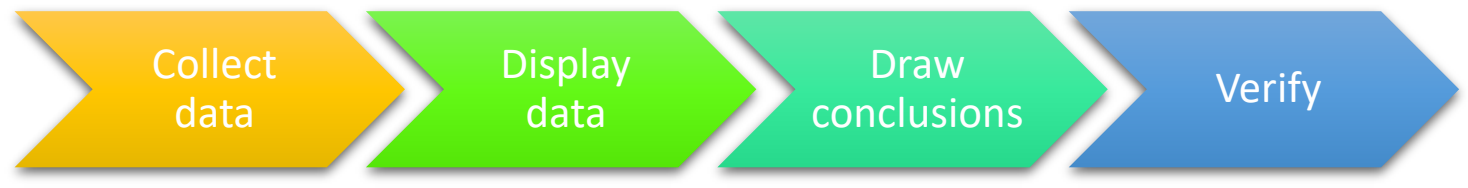

Figure 1. Flow analysis flow (flow model analysis) (Sugiyono, 2019) 


\section{RESULTS AND DISCUSSION}

The results showed that; COVID-19 prevention education through PHBS for early childhood at Raudlatul Athfal Pakuniran is carried out as follows:

\section{Preparation and Planning Analysis}

Before a program is implemented by a teacher who is obliged to prepare complete and systematic learning materials that will be delivered to students, in addition to material, the teacher must also prepare interesting, innovative, and fun learning models. At this stage, the arrangement of activities for implementing PHBS has been prepared in advance by the teacher arranged through the $\mathrm{RPPH}$, which is made in designing learning at Raudlatul Athfal Pakuniran based on the existing curriculum.

IF1 Head of Raudlatul Athfal Pakuniran conveyed some of the preparations made by the teacher before the teaching and learning process. in the form of Prota, Prosem, Rppm, and Rpph according to the Raudlatul Athfal (RA) level curriculum. Thus, the teacher already has a reference or guide to prepare for the learning process from annual, semester, weekly, and daily. Raudlatul Athfal Pakuniran has been one of the RAs implementing health education since its inception, namely in 2015. The health education carried out is the implementation of hygiene, such as the habit of washing hands before and after eating, throwing garbage in its place; this is emphasized more profoundly considering the emergence of COVID 19 in the hope that children will not get infected with the virus, this is in line with the government's announcement in preventing COVID 19, everyone is required to wash their hands regularly, and get used to a healthy lifestyle by consuming four healthy five perfect foods to strengthen immunity.

IF2 as teacher Raudlatul Athfal Pakuniran conveyed that in the implementation of PHBS, PHBS program facilities and infrastructure provide handwashing places, soap, hand sanitizers, trash bins, and other necessities.

IF3 as the homeroom teacher for group A said, that the PHBS program at Raudlatul Athfal Pakuniran has only been implemented for four years, only for the implementation of the cleanliness itself, we have monitored it from the start, in health, it is called PHBS if at Raudlatul Athfal Pakuniran it has a program called 5 GENBA, which is one of the programs that has Raudlatul Athfal Pakuniran to control the cleanliness of his students, but since January a healthy lifestyle has been massively promoted to prevent the spread of COVID 19 which is currently worldwide as anticipation for all of us in general and especially for our children, supported by all parties from both the Foundation and the guardians of students (Umiarso \& Hidayati, 2022).

IF4 as the homeroom teacher for group B, also emphasized that the supporting role in PHSB activities is constructive in carrying out the success of the PHBS program, which is being promoted at the Raudlatul Athfal Pakuniran institution. The provision of funds indicates the excellent support given by the foundation and the guardians of students to facilitate the lack of facilities in the PHBS program.

Analysis of preparation and planning needs to be carried out to ripen the program that has been planned for the sake of planning and implementing the program that is the target goal of an institution.

\section{PHBS Program Implementation}

Implementation is carried out in the application of clean and healthy living behavior through the following activities:

\section{Washing hands with soap}

In everyday life, especially in the school environment, the children of Raudlatul Athfal Pakuniran are taught to wash their hands properly, wash their hands with soap, use running water and clean all parts of their hands, including between the fingers. Washing hands is one 
of the efforts promoted by the government in the era of COVID 19 because it is considered a reasonable effort to prevent the virus; following up on this Raudlatul Athfal also intensified children to behave in a healthy and clean life, one way is by washing their hands properly (figure3).

IF1 said that through the habit of washing hands, students could get used to living clean and healthy, considering that the world is being hit by an epidemic called COVID 19, this needs to be encouraged, but it does not mean that without Covid-19, children do not behave healthily, but they are taught and implemented.

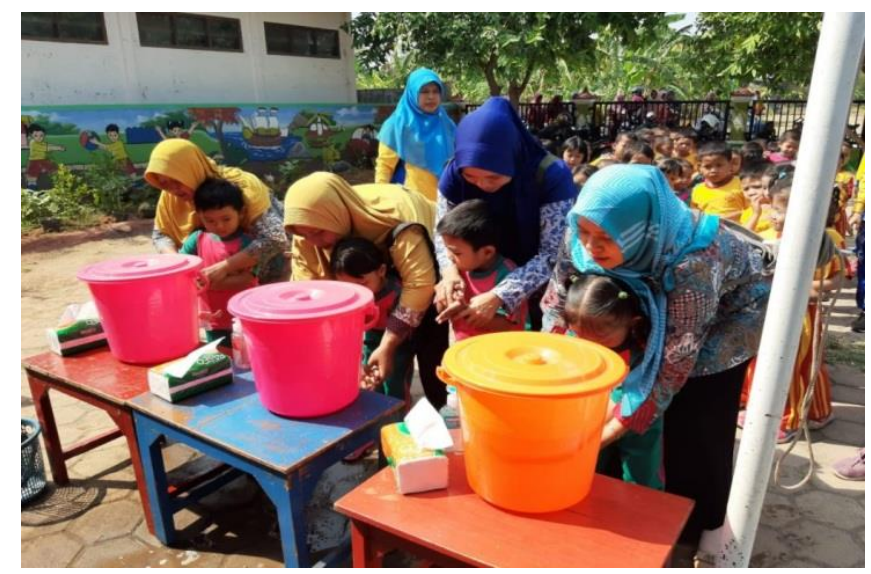

Figure 3. Handwashing Activities

Source: Research documentation

\section{Eat nutritious foods}

Counseling and providing healthy food to children is essential to be done by teachers. Healthy food is food that contains substances needed by the body. Healthy food is nutritious, hygienic, does not contain germs that harm health. The composition of nutrients is carbohydrates, fats, proteins, vitamins, minerals, and water. These healthy foods will provide a sound immune system for children and affect optimal child development. Nutritious supplementary food is delivered every Wednesday. Offer additional food as long as researchers make observations at Tahdzibun Nasyiin Pakuniran.

IF3 said that the school holds every parenting semester or seminar by inviting parents to a parenting event about the meaning of healthy and nutritious food. Parenting provides understanding for parents of students about tricks and how to process healthy and nutritious food that will give to children.

IF2 explained that it is not only counseling carried out by the school but also a program of providing other food, of course, healthy and nutritious food, given to students once a month. The provision of healthy and nutritious supplementary food indirectly stimulates the habituation of healthy food consumed by students.

\section{Clean yourself (hands and nails)}

In addition to cleaning hands by washing them, nail hygiene is carried out regularly for the children of Raudlatul Athfal Pakuniran. IF1 conveyed that nail hygiene checks are carried out weekly, usually scheduled every Friday. Because cutting nails on Friday is a sunnah of the Prophet. It is also essential to cut nails regularly for children because their claws, usually dirty, contain lots of germs and bacteria. If this is not taught to children and not cleaned often, it will undoubtedly endanger children's health and affect children's development.

\section{Maintaining the health of the surrounding environment}

Raudlatul Athfal Pakuniran has a Healthy Friday program; this healthy Friday includes the first two things, sports and cleaning the school environment. Exercise is scheduled 
every Friday through gymnastics and healthy walks; this is applied to children to maintain health and increase endurance.

IF3 said that sports activities are very popular with students of Raudlatul Athfal Pakuniran because children do body exercises accompanied by music such as gymnastics, so they are very enthusiastic in participating in these activities. In addition, running and ball tending are also the most popular sports games. The next is related to environmental cleaning. In this activity, the school implements simple learning related to ecological health, including cleaning the school environment and collecting garbage that involves all students. If the domain is clean and healthy, there is great hope that children will not be exposed to bacteria and viruses. IF4 said that we also encourage throwing garbage in its place with the "ant operation" joke when the teacher gives a signal by saying that it is an ant operation. Hence, students are ready to pick up trash in the school environment to pick it up and throw it in its place.

\section{Checking the child's health}

Health checks on the children of Raudlatul Athfal Pakuniran in collaboration with the Pakuniran Health Center. This examination aims to provide health services to Raudlatul Athfal Pakuniran children regularly. IF1 said that this health check is carried out every month, with periodic checks giving a positive response and knowing early detection of health in students. In addition, children are also guided on maintaining health, such as brushing their teeth and practicing the correct way of brushing their teeth during health checks. Through the implementation of the PHBS program, it can provide understanding for students and guardians of students and the school environment regarding the importance of clean and healthy living behavior in the implementation of community life.

\section{Program Evaluation}

Program evaluation is carried out to determine an objective and systematic assessment of planned intervention, in progress or completed. Evaluation PHBS can be interpreted as a series of activities comparing the realization of inputs (inputs), outputs (outputs), and results (outcomes) against plans and standards. Evaluation results are obtained during the monitoring activities. More than that, the evaluation also assesses the results or products that have been produced from a series of programs as a basis for making decisions about the level of success that has been achieved and the following action required.

IF1 says things that are evaluated in PHBS activities are; regarding the completeness of facilities and infrastructure, tricks and methods of teachers in inviting clean and healthy living habits, and the provision of parenting that can give enthusiasm to the environment to implement PHBS.

In conducting the evaluation, the institution involved parties from the foundation in assessing ongoing activities; all findings were used as guidelines for taking the following steps that could improve the program. By evaluating the program, institutions and foundations can predict failures and minimize program failures.

Requires an analysis of preparation and planning before starting a program to make it easier for teachers to implement activities delivered to students. Teaching preparation can be used as a basis for preparing lesson plans and at the same time as a teacher reference in carrying out learning activities so that they are more directed and run efficiently and effectively (Astuti et al., 2020). Preparation of teaching media can and learning tricks must also be done by a teacher before entering the class (Baharun, 2016; Zamroni et al., 2021) . Through careful preparation, the teacher makes it easier to determine the themes and learning materials they will apply (Astriani, 2019).

Learning planning is an activity of projecting what actions will be carried out in a lesson, namely by arranging and responding to learning components, so that the direction of the movement (goals), side of activities (material), how to deliver activities (methods and 
techniques), and how to measure them (evaluation) becomes explicit and systematic (Baharun, 2016; Hanifah \& Amaliah, 2018; Hefniy et al., 2019).

Implementation of the teaching and learning process for students in several ways to prepare quality human resources and form a complete personality (Silviani et al., 2021; Trihapsari \& Mujahidah, 2021). Therefore, in providing learning materials, some aspects must be developed and instilled in students, including cognitive, language, religious, moral, and social values. The education provided must touch on social elements, including tolerance, caring, mutual respect, mutual respect, working together, empathy, and so on (Qasim \& Maskiah, 2016)

In conducting the evaluation, the institution involved parties from the foundation in assessing ongoing activities; all findings were used as guidelines for taking the following steps that could improve the program. By evaluating the program, institutions and foundations can predict failures and minimize program failures (Zamroni \& Qatrunnada, 2021). Evaluations that are often encountered so far in education are limited to assessments. This assessment is carried out in a formative and summative manner (Mahmud \& Suratman, 2019). When the assessment has been carried out, the assessment has been evaluated. Understanding is too precise. Its implementation tends to only look at the achievement of learning objectives. In fact, in the educational process, it is not only the value seen but many things that make a program successful or not. Assessment is only a tiny part of the evaluation. Evaluation should also reach out as part of supervision. Evaluation is not only an assessment of the value measured based on problem-solving, but the evaluation of educational programs will examine many factors. Thus, evaluation programs need to be introduced to educators because evaluation is critical in developing the quality of education (Munthe, 2015)

Evaluation can encourage students to be more active in learning continuously and encourage teachers to improve the quality of the learning process further and enable schools to enhance other facilities and the quality of student learning (Mahirah, 2017). The purpose of the evaluation is that the plans made can achieve the goals that have been set and can be implemented. The assessment results are for re-planning and serve as the final administration and management.

\section{CONCLUSION}

Implementation of Clean and Healthy Life Behavior (PHBS) is a collection of behaviors that are practiced based on awareness due to learning. The PHBS pattern intends to motivate children to play an essential role in realizing physical health or body health through concrete actions taken in the school environment. Prevention of Covid-19 is done by teaching children to take care of their healthy lifestyle, starting with washing hands with soap, eating nutritious food, and maintaining the cleanliness of the body. In addition, the implementation of clean living is carried out from an early age in children's daily lives.

\section{ACKNOWLEDGEMENT}

The researcher would like to thank the Rector of the University of Nurul Jadid, Paiton, Probolinggo, East Java, who has supported researchers to complete this research. The researcher also thanks to the Obsession Journal's editorial team for providing the opportunity for researchers to publish the results of this study.

\section{REFERENCES}

Adham, A. S., \& Mahmudah, F. N. (2021). "Art and Culture" Learning Management for Students' Increased Achievement During the Covid-19 Pandemic. Al-Tanzim: Jurnal Manajemen Pendidikan Islam, 5(1), 106-114. https://doi.org/10.33650/altanzim.v5i1.1904 
Afrida, R. N., Hardini, D. S., \& Purnomo, A. (2020). Pengaruh Bermain Teraupetik Puzzle Terhadap Tingkat Kecemasan Anak Usia Pra Sekolah Di Ruang Anak Rs Bhayangkara Anton Soedjarwo Pontianak. Khatulistiwa Nursing Journal, 2(2). https:// doi.org/10.53399/knj.v2i2.46

Agusniatih, A., \& Manopa, J. M. (2019). Keterampilan Sosial Anak Usia Dini: Teori dan Metode Pengembangan . Edu Publisher.

Andin, A. H., Titis, C. Z., \& Hakim, A. H. Z. F. (2021). Penerapan Perilaku Hidup Bersih dan Sehat di Masa Pandemi Covid 19. Early Chilhood: Jurnal Pendidikan, 5(1), 78-88. https://doi.org/10.31004/obsesi.v5i1.555

Apriliani, F. T., Wibowo, H., Humaedi, S., \& Irfan, M. (2020). Model Keberfungsian Sosial Masyarakat Pada Kehidupan Normal Baru. Jurnal Kolaborasi Resolusi Konflik, 2(2), 133-141. https:// doi.org/10.24198/jkrk.v2i2.29123

Ariyanti, T. (2016). Pentingnya Pendidikan Anak Usia Dini Bagi Tumbuh Kembang Anak. Dinamika Jurnal Ilmiah Pendidikan Dasar, 8(1).

Astriani, S. A. (2019). Pendekatan Webbed Learning Pada Pembelajaran Tematik Terhadap Peserta Didik Inklusif Di Madrasah. Journal AL-MUDARRIS, 2(1), 79. https://doi.org/10.32478/al-mudarris.v2i1.220

Astuti, D. P., Muslim, A., \& Bramasta, D. (2020). Analisis Persiapan Guru Dalam Pelaksanaan Pembelajaran Matematika Di Kelas Iv Sd Negeri Jambu 01. Jurnal Wahana Pendidikan, 7(2), 185-192. https://doi.org/10.25157/wa.v7i2.3676

Baharun, H. (2016a). Pengembangan Media Pembelajaran PAI Berbasis Lingkungan Melalui Model ASSURE. Cendekia: Journal of Education and Society, 14(2), 231-246. https://doi.org/10.21154/cendekia.v14i2.610

Baharun, H. (2016b). Penilaian Berbasis Kelas pada Pembelajaran Pendidikan Agama Islam di Madrasah. MODELING: Jurnal Program Studi PGMI, 3(2), 205-2016.

Dewi, I. P. (2021). Edukasi Protokol Kesehatan untuk Komitmen Kepatuhan Pencegahan Penularan dan Edukasi Spiritual untuk Menurunkan Kecemasan Masa Pandemi Covid-19 Melalui Kulwap. Media Karya Kesehatan, 4(1), $12-27$.

Dewi, Y. K. (2016). Hubungan Antara Kematangan Emosi Anak Usia Dini dan Metode Bcct (Beyond Center And Circles Time) Ditinjau dari Pemahaman Orang Tua Siswa Dan Guru di PAUD Pelangi dan Mega Buana, Motivasi, 3(1), 111-145.

Fahrika, A. I., \& Roy, J. (2020). Dampak pandemi covid 19 terhadap perkembangan makro ekonomi di indonesia dan respon kebijakan yang ditempuh. INOVASI, 16(2), 206-213.

Hakiki, N., \& Khotimah, K. (2020). Penggunaan Permainan Edukatif Tradisional dalam Mengembangkan Motorik Kasar Anak Usia Dini. PRESCHOOL: Jurnal Pendidikan Anak Usia Dini, 1(1), 22-31. https:/ / doi.org/10.35719/preschool.v1i1.3

Hanifah, H., \& Amaliah, F. (2018). Manajemen Pembelajaran Bagi Anak Usia Dini dalam Meningkatkan Kualitas Pembelajaran di Pos PAUD Dahlia 15. Jurnal Comm-Edu, 1(3), 24-29. https:// doi.org/10.22460/comm-edu.v1i3.1102

Hayati, Z. (2019). Penggunaan Alat Permainan Edukatif (Ape) Dari Botol Plastik Dan Koran Bekas Untuk Meningkatkan Kreatifitas. AWLADY : Jurnal Pendidikan Anak, 5(1), 5679. https:// doi.org/10.24235/awlady.v5i1.3457

Hefniy, Fauzi, A., Faridy, \& Fatmasari, R. (2019). National assessment management based on information and communication technology and its effect on emotional intelligence learners. Journal of Physics: Conference Series, 1175(1), 9-13. https://doi.org/10.1088/1742-6596/1175/1/012225

Ida Yeni Rahmawati, Siti Asiyah, D. M. (2020). Aplikasi Klonosewandono Sebagai Bahan Ajar Bipa Pada Keterampilan Membaca Tingkat Dasar. JDPP : Jurnal Dimensi Pendidikan Dan Pembelajaran, 8(3), 117-124.

Iltiqoiyah, L. (2020). Manajemen Pembelajaran melalui Pendekatan BCCT dalam Meningkatkan Multiple intelligences Anak. Jurnal Obsesi : Jurnal Pendidikan Anak Usia Dini, 5(2), 1368-1381. https://doi.org/10.31004/obsesi.v5i2.781 
Julianti, R., Drs. H. M Nasirun, M. P., \& Wembrayarli, S.Pd, M. S. (2018). Pelaksanaan Perilaku Hidup Bersih Dan Sehat (Phbs) Di Lingkungan Sekolah. Jurnal Ilmiah Potensia, 3(2), 11-17.

Julianti, R., Nasirun, M., \& Wembrayarli, W. (2018). Pelaksanaan Perilaku Hidup Bersih dan Sehat (Phbs) di Lingkungan Sekolah. Jurnal Ilmiah Potensia, 3(2), 76-82. https:// doi.org/10.37849/mipi.v2i2.168

Kamelia, N. (2019). Perkembangan Fisik Motorik Anak Usia Dini (Standar Tingkat Pencapaian Perkembangan Anak) Stppa Tercapai Di Ra Harapan Bangsa Maguwoharjo Condong Catur Yogyakarta. KINDERGARTEN: Journal of Islamic Early Childhood Education, 2(2), 112-136. https:// doi.org/10.24014/kjiece.v2i2.9064

Khomaeny, E. F. F., Ulfah, M., \& Hamzah, N. (2020). Pengaruh Aktivitas Fisik Dan Lingkungan Alamiah Bagi Daya Tahan Tubuh Anak Usia Dini. AWLADY: Jurnal Pendidikan Anak, 6(2), 234-252. https:// doi.org/10.24235/awlady.v6i2.6206

Mahirah. (2017). Evaluasi Belajar Peserta Didik (Siswa). Idaarah: Jurnal Manajemen Pendidikan, 1(2), 257-267. https:// doi.org/10.24252/idaarah.v1i2.4269

Mahmud, M. E., \& Suratman, S. (2019). Evaluasi Program Manajemen Pembelajaran Pada Sekolah Adiwiyata Kalimantan Timur. Al-Tanzim: Jurnal Manajemen Pendidikan Islam, 3(2), 85-96. https:/ / doi.org/10.33650/al-tanzim.v3i2.691

Mardhiati, R. (2013). Pesan Kesehatan : Perilaku Hidup Bersih Dan Shat (Phbs) Anak Usia Dini Dalam Kurikulum Pendidikan Anak Usia Dini. Jurnal Ilmiah Kesehatan, 2(3), 1-14. https:// doi.org/10.35952/jik.v2i3.71

Mundiri, A., \& Jannah, F. (2021). Quality Assurance of Education in Senior High School during Covid-19 Pandemic. Al-Ishlah: Jurnal Pendidikan, 13(3), 2203-2212. https:// doi.org/10.35445/alishlah.v13i3.1190

Munthe, A. P. (2015). Pentingya Evaluasi Program Di Institusi Pendidikan: Sebuah Pengantar, Pengertian, Tujuan Dan Manfaat. Scholaria, 5(2), 1-14. https:// doi.org/10.24246/i.scholaria.2015.v5.i2.p1-14

Mustain, M., Wulansari, W., \& Novichasari, S. I. (2021). Peningkatan Pengetahuan Perilaku Hidup Bersih dan Sehat Melalui Permainan Ular Tangga. Diseminasi Fakultas Kesehatan , 1 (1)., 1.

Mustajab, M., \& Fawa'iedah, Z. (2020). Adapting to Teaching and Learning During Covid-19: A Case of Islamic School's Initiative of Self-regulated Learning. Nadwa, 14(2), 241-264. https://doi.org/10.21580/nw.2020.14.2.6515

Nurhasanah. (2019). Pengembangan Sarana Kegiatan dan Sumber Belajar di Taman KanakKanak. Didaktika: Jurnal Kependidikan, 12(1), 46-61. https:// doi.org/10.30863/didaktika.v12i1.175

Nurmahmudah, E., Puspitasari, T., \& Agustin, I. T. (2018). (2018). Perilaku hidup bersih dan sehat (PHBS) pada anak sekolah. ABDIMAS: Jurnal Pengabdian Masyarakat, 1(2), $46-$ 52. https:// doi.org/10.35568/abdimas.v1i2.327

Pamungkas, R. A., Abdurrasyid, A., Gobel, S., Maria, W., Neliyana, N., Savira, N. A., \& Ulpiah, S. (2021). Pencegahan Penularan Infeksi Covid 19 Pada Anak Usia Dini Melalui Personal Protective Equipment (PPE). Seminar Nasional \& Call Of Papers Penelitian Dan Pengabdian Masyarakat, 1(1).

Pujianto, D. (2019). Aktivitas Jasmani dan Persepsi Gerak Anak Usia Dini. Halaman Olahraga $\begin{array}{lllll}\text { Nusantara } \quad \text { Jurnal } & \text { 7lmu-87. }\end{array}$ https://doi.org/10.31851/hon.v2i1.2467

Qasim, M., \& Maskiah. (2016). Perencanaan Pengajaran Dalam Kegiatan Pembelajaan. Jurnal Diskursus Islam, 4(3), 484-492.

Qomariyah, N. (2021). Interview.

Rahman, A., \& Subiyantoro, S. (2021). The Leardership Role of School Principals in Online Learning During the Covid-19 Pandemic. Al-Tanzim: Jurnal Manajemen Pendidikan Islam, 5(1), 165-175. https:/ / doi.org/10.33650/al-tanzim.v5i1.1805 
DOI: 10.31004/obsesi.v6i4.2075

Rifqi, A. (2021). Regional Based KKN Management: Toward Freedom of Learning During the Covid-19 Pandemic. Al-Tanzim: Jurnal Manajemen Pendidikan Islam, 5(1), 95-105. https:// doi.org/10.33650/al-tanzim.v5i1.1866

Silviani, S., Maarif, M. A., \& Wibowo, A. (2021). Knowledge Sharing Management: Strategy for Improving the Quality of Human Resources. Al-Tanzim: Jurnal Manajemen Pendidikan Islam, 5(1), 129-139. https:// doi.org/10.33650/al-tanzim.v5i1.1831

Suhairi, \& Badrudin. (2021). Implementation of Academic Supervision of Islamic Religious Education During The Covid-19 Pandemic. Curriculum Management In Improving Competitive Advantage in 20 -30. https://doi.org/10.52627/ijeam.v3i2.129

Sukatin, S., Chofifah, N., Turiyana, T., Paradise, M. R., Azkia, M., \& Ummah, S. N. (2020). Analisis Perkembangan Emosi Anak Usia Dini. Golden Age: Jurnal Ilmiah Tumbuh Kembang Anak Usia Dini, 5(2), 77-90. https:// doi.org/10.14421/iga.2020.52-05

Tabi'in, A. (2020). Perilaku hidup bersih dan sehat(phbs) pada anak usia dini Sebagai upaya pencegahan covid 19. JEA (JURNAL EDUKASI AUD), 6(1), 58-73. https:// doi.org/10.18592/jea.v6i1.3620

Trihapsari, C., \& Mujahidah, F. (2021). Enhancement of the Quality of Human Resources Through Training and Development Programs in Schools. Al-Tanzim: Jurnal Manajemen Pendidikan Islam, 5(2), 145-153. https://doi.org/10.33650/altanzim.v5i2.2325

Umiarso, \& Hidayati, N. (2022). Improving Children â€TM s Cognitive Intelligence Through Literacy Management. Jurnal Obsesi: Jurnal Pendidikan Anak Usia Dini, 6(3), 15881598. https:// doi.org/10.31004/obsesi.v6i3.1817

Zamroni, \& Qatrunnada, W. (2021). Utilization of Digital Applications in Learning Assessment Utilization of Digital Applications in Learning Assessment. Journal of Physics: Conference Series, 1899, 1-5. https:/ / doi.org/10.1088/1742-6596/1899/1/012156

Zamroni, Amir, \& Saleha, L. (2021). Pengelolaan APE Berbahan Limbah untuk Meningkatkan Kecerdasan Kognitif Anak. Jurnal Obsesi: Jurnal Pendidikan Anak Usia Dini, 5(2), 1382-1395. https:// doi.org/10.31004/obsesi.v5i2.763 